\title{
Business Models and Sustainability in Nature Tourism: A Systematic Review of the Literature
}

\author{
Samira Sahebalzamani ${ }^{1, * \mathbb{D}}$ and Giovanna Bertella ${ }^{2}$ (D) \\ 1 The School of Business and Economics, UiT-The Arctic University of Norway, 9510 Alta, Norway \\ 2 The School of Business and Economics, UiT-The Arctic University of Norway, 9037 Tromsø, Norway; \\ giovanna.bertella@uit.no \\ * Correspondence: samira.sahebalzamani@uit.no; Tel.: +47-784-503-79
}

Received: 13 August 2018; Accepted: 7 September 2018; Published: 10 September 2018

\begin{abstract}
This study explores the business model literature within nature tourism, focuses on its sustainability-related aspects, and adopts some of the results of the literature review by Reinhold et al. The research questions concern how scholars use and operationalize the business model concept in the context of nature tourism, and to what extent sustainability-related aspects are included and discussed. A literature review was conducted including a total of 18 scientific articles from various disciplines. The findings suggest that scientific literature about business models in nature tourism is very limited, both in relation to the number of articles and their content. With regard to the latter, the business model concept is sometimes adopted without any clear definition, sustainability-related aspects—especially those relative to the environmental dimension-are scarcely discussed, the perspective adopted is usually static, and innovation for sustainability is only marginally included. This indicates a clear gap in the literature and a considerable potential for future studies.
\end{abstract}

Keywords: business models; nature tourism; sustainability

\section{Introduction}

This study presents a literature review concerning the understanding and operationalization of the business model concept in nature tourism, with particular focus on the extent and the way that this concept is discussed in relation to sustainability-related aspects.

The business model concept is broadly adopted by business and management scholars as a strategic construct delineating the underlying logic through which value can be created and captured [1,2]. Some scholars explicitly relate this concept to sustainability [3,4], which can be described with reference to the "triple bottom line" short- and long-term impacts: economic, social, and environmental benefits and risks $[5,6]$. The importance of the inclusion of sustainability in relation to business models derives from the limitations that other approaches, for example corporate social responsibility, seem to have in the creation of the needed radical transformation of organizations and industries [7].

It is only recently that some scholars have adopted the business model concept in tourism and the literature is scant in regard to sustainable business models therein $[8,9]$. This study aims to contribute to such literature focusing on nature tourism, a form of tourism where sustainability-related impacts have concerned several scholars [10-13]. For the purpose of the study, nature tourism is understood in a broad way, comprising all forms of tourism centered on activities performed in wild nature as well as in more domesticated nature, including, for instance, adventure tourism, wildlife tourism, and rural tourism $[14,15]$. 
This study's underlying assumption is that business models are potentially relevant strategic management tools for sustainability [16]. Based on such considerations, this study conducts a literature review posing the following questions. How is the business model concept used and operationalized within scientific articles about nature tourism? To what extent and how do these articles include and discuss sustainability-related aspects?

This paper begins with presenting the theoretical concepts on which the literature review is based. The method for conducting the literature review is then described, followed by presentation of the findings and their discussion. The conclusion highlights the main results and indicates directions for future nature tourism studies.

\section{Business Models, Sustainability, and Nature Tourism}

\subsection{The Business Model Concept}

The business model concept became popular in the 1990s to describe how new kinds of businesses, such as online content providers and web services, emerged and became profitable [17]. One of the most accepted business model definitions is by Teece (2010) [18], which refers to a business model as the way an enterprise, explicitly or implicitly, understands and describes the design of the value creation, delivery, and capture mechanisms. More precisely, the author defines the essence of a business model as "the manner by which the enterprise delivers value to customers, entices customers to pay for value, and converts those payments to profit" [18] (p. 172). In other words, the business model carries "implicit assumptions" about customers, cost structures, revenue flows, competitors' behavior, and shifts in user needs, and ultimately, the way in which the firm "goes to market" [18].

While Teece (2010) [18] describes business models referring to three value related processes-"value proposition", "value creation", and "value capture"—-some scholars have developed rather detailed analytical frameworks. Among these, the business model Canvas is broadly applied by both scholars and practitioners due to its holistic approach and flexibility. It permits businesses to obtain an analytic overview based on nine main components: "value proposition", "key activities", "key resources", "customer relationship", "channels", "key partners", "customer segments", "cost structure", and "revenue streams" [19,20]. A selection of these components is also included in other frameworks, such as those by Boons and Lüdeke-Freund [21], Afuah [22], and Wirtz et al. [23].

It has been emphasized that the business model can play a crucial role in a firm's strategy by bridging strategy formulation and implementation, since the business model explains how the activities of the firm operate together to carry out its strategy [24]. Moreover, business models are studied as potential tools at various levels, from product, to business unit, company, and industry [3].

In line with the broader business and management literature, within the recent business model literature it is highlighted that value creation is not to be viewed exclusively in terms of financial success related to revenue and sales, but as a collaborative process among firms and various stakeholders, via informal and/or formal channels, aiming to achieve benefits beyond firm profitability $[7,25]$. Another focus of the recent literature is the adoption of a dynamic perspective whereby business model innovation and transformation are viewed as critically important elements [26,27]. The debate regarding sustainable business models can be inserted in this context.

\subsection{Sustainable Business Models}

Some business model scholars argue that in order to contribute to sustainable development, organizations need to reconsider their business models $[4,28,29]$. The concepts of sustainability and sustainable development date back to the end of the 1980s; since then, several scholars from various disciplines have investigated these concepts in an attempt to clarify their meaning and application and highlight their related strengths and weaknesses [6,30,31]. Sustainable development was defined in 1987 as "development that meets the needs of the present without compromising the ability of future generations to meet their own needs" [5] (p. 41). The present and future generations' needs 
are usually described with reference to the "triple bottom line", a perspective that includes economic, environmental, and social factors [6]. This perspective is adopted broadly, either implicitly or explicitly, by firms because it refers to the concept of sustainability in a relatively simple and clear way [32]. Sustainability has been also commented on in terms of conducting innovation and change in order to cope with the environment in which companies are operating [33].

Along with the socioeconomic and environmental factors relating to business models, innovation is a relevant aspect within business models that aim for sustainability. Business model innovation (BMI) is discussed in the literature as a tool through which sustainability can be integrated into the business [28,33-37]. An example of this dynamic perspective is the classification by Cavalcante et al. [34] that defines four types of change related to business models: business model creation (conceptualization of a new business model), business model extension (expanding the business but keeping the key processes of the existing one), business model revision (replacing the business model with a new one), and business model termination (relinquishing the existing business model).

This dynamic perspective can be commented by referring to two types of sustainability: strong and weak. Strong sustainability can be associated with radical change, and it focuses on the complete integration of sustainability within the core processes of the business. Weak sustainability concerns incremental changes and the adaption of some activities, which leads to partial transformation aimed at achieving a sustainable business model [4]. Boons et al. [35] argue that incremental changes towards weak sustainability are not enough when it comes to contributing to sustainable development; thus, business transformation must go farther.

\subsection{Sustainable Business Models in Tourism}

Reinhold et al. [8] conducted a literature review of scholarly articles making explicit use of the business model concept in tourism and analyzed a total of 28 articles. The authors identify the following main themes: sector-specific configurations (tourism and hospitality, transportation, and e-commerce); the role of different value types; design themes for consistency; and regulatory contingencies. Sustainability as a popular concept is debated in the tourism literature in relation to both potential and challenges [30,31,38,39]; they are discussed within each of the main themes identified by Reinhold et al. [8].

As presented by Reinhold et al. [8] within the first identified theme, some scholars have challenged the idea of integrating the sustainability aspect in destination business model design and in hospitality management practices [40-44]. Within the second theme concerning value types, sustainability-related considerations in tourism tend to be focused on the benefits the local residents can gain from different business models [41,43-46]. Sustainability is a major topic within the third theme, design for consistency. Here, hospitality business models [41,42], ecotourism [43], and wine tourism business models [47] are discussed together with destination offerings [43]. Sustainability also appears in the theme related to regulations and refers to lodging firms [48,49].

Based on these considerations, this study conducts a literature review focused on nature tourism, investigating how the concept of the business model is used and operationalized by scholars, particularly in relation to environmental, social, and economic sustainability. Moreover, the sustainability aspect is also included in this study in relation to innovation. Innovation is identified by several tourism studies as being relevant to sustainability [50-52]. For example, Gössling et al. [51] assert that "sustainability itself was, and arguably still is, an innovative idea" [51] (p. 5). Hjalager [52] identifies the following types of innovation within tourism sector: product/service; process; management; managerial (marketing); and institutional. Institutional innovation is defined as a "collaborative/organizational structure or legal framework that efficiently redirects or enhances the business" [52] (p. 3) and may "constitute more widespread changes" [52] (p. 4). If fully embraced, sustainable business models can constitute a form of institutional innovation that can contribute to strong sustainable goals. 
It has been observed that the tourism studies concerning sustainable business models elaborate more on economic rather than social and environmental sustainability, and the concept of the environmental value proposition is neglected [9,13]. In a literature review by Reinhold et al. [8], only a minority (five) of the selected studies contribute to nature tourism $[43,44,47,53,54]$ and merely two out of these studies address sustainability aspects $[43,44]$.This indicates a gap in the literature that is particularly problematic, because nature tourism is often discussed in relation to sustainability [10-12], due to its dependence on the natural environment (environmental challenges) and its setting sometimes characterized by vulnerable social contexts such as those of rural and peripheral areas (social challenges) [55].

\section{Methods}

A literature review is a distinctive form of research that aims to create new knowledge about a specific topic using existing literature that covers this topic [56]. Literature reviews can facilitate theory development, and thus contribute to closing possible gaps and revealing areas where further research is needed [57]. The present literature review is performed systematically following the phases described below [58], starting from the research questions:

- RQ1: How is the business model concept used and operationalized within scientific articles about nature tourism?

- RQ2: To what extent and how do these articles include and discuss sustainability-related aspects?

The first question is suggested by Reinhold et al. [8] among the conclusions derived from their literature review about business models in tourism, and refers to one of the main directions for a future research agenda. The second question indicates this study's focus on sustainability as a relevant aspect of the investigated form of tourism, and on innovation as a critically important factor.

This literature review is conducted following the phases identified in Seuring and Muller [59] on the basis of Mayring [60]. The articles included in the review were collected and delimitated. In this phase, nature tourism studies were selected using two databases broadly used and recognized as reliable within the international scientific community: ISI Web of Science and ProQuest. The time range for the analysis was January 2000 to November 2017. This time range was chosen as the result of a preliminary search including publications from 1990 showing no match for the research criteria.

The search words used in this selection were "business model", tourism, and sustain (which can include both the words sustainability and sustainable). The search words were considered relevant when appearing in the title and/or the abstract and/or the list of keywords. One selection criterion was that the terms "business model" and tourism were both present.

The keyword search "business model" was written with quotation marks, since we aimed to find the exact phrase; otherwise, the research result might also include inquiries addressing either the word business or the word model, which could not satisfy our criteria. By exploring these two databases, we obtained 249 articles. The review process is demonstrated in Figure 1. As shown in Figure 1, the total number of 231 articles was considerably reduced. This was done due to several reasons:

1. Fifty-six articles were present in both databases;

2. In 66 articles the business model concept was used marginally and was only loosely related to the context;

3. For 18 of the remaining articles, there was no access to the full text because they were conference proceedings;

4. In 91 of the remaining articles there was no focus on nature tourism.

Through this selection process, 18 articles were identified as being relevant for in-depth analysis. These 18 articles are described in relation to relevant aspects. They are presented in detail in the first part of following section, both graphically (Table 1) and in the text. 


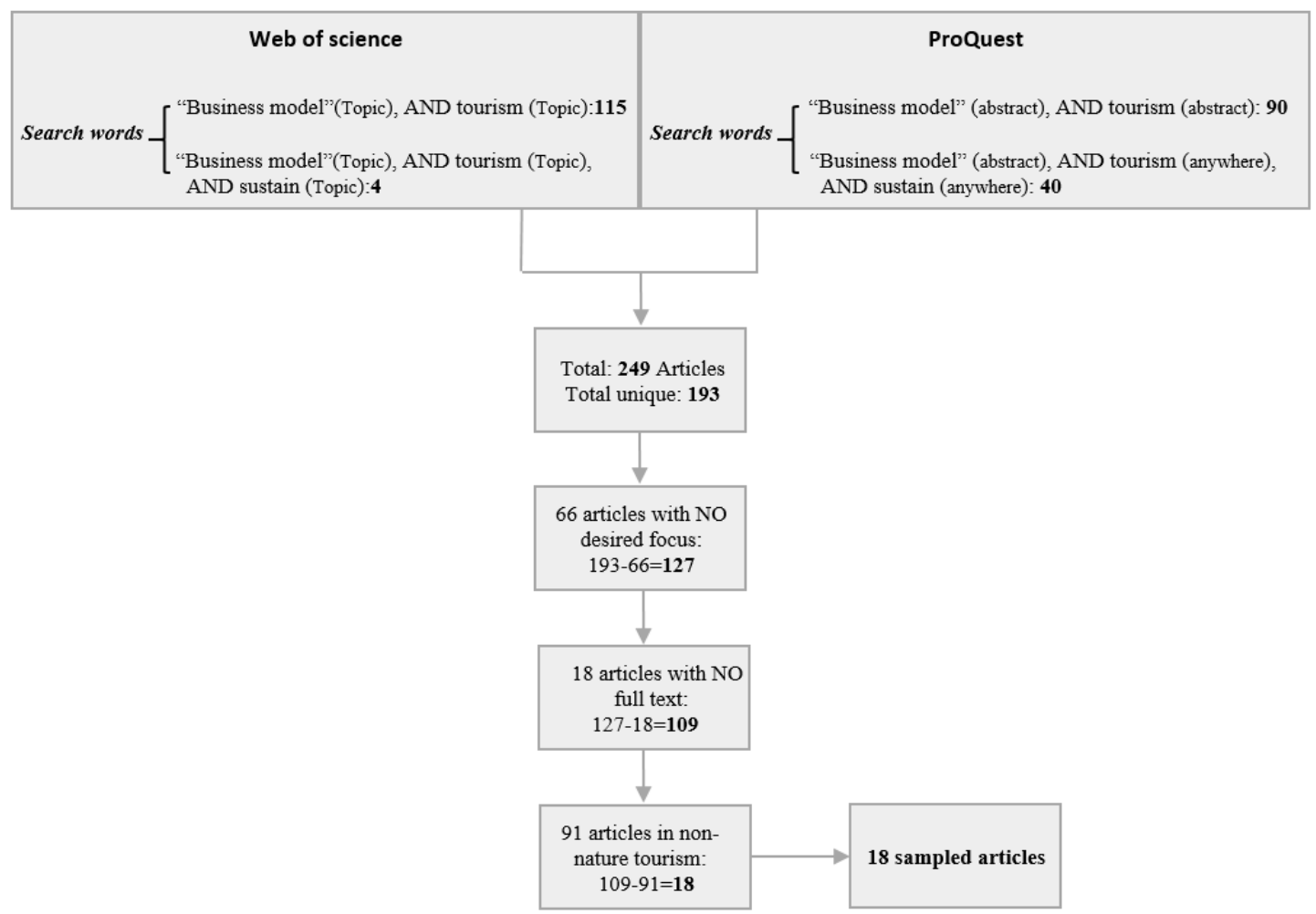

Figure 1. Systematic literature review (2000-1 November 2017).

The following phase concerned the analysis of the 18 selected articles using categories and subcategories related to the two research questions and identified as relevant on the basis of the business model and sustainable tourism literature presented previously. The categories and subcategories are:

- Conceptualization and operationalization: business model as a descriptive tool/positivistic approach; as a cognitive schema/constructive approach, and as a conceptual tool/predefined framework.

- Sustainability-related aspects: economic, social, environmental impacts, and innovation for sustainability.

This analysis is presented both graphically (Table 2) and in the text in the second part of the following section.

\section{Literature on Business Models and Sustainability in Nature Tourism}

\subsection{Overview of Reviewed Literature}

As mentioned above, 18 articles were selected. They were published under different disciplines which we categorize into five groups as they were published in different journals belonging to five different fields of studies, more specifically:

1. Business, Management and Marketing (five articles) in the journals Sport, Business and Management: An International Journal [61], Journal of Enterprising Communities: People and Places in the Global Economy [62], Academy of Entrepreneurship Journal [63], Local Economy [64], and Journal of Business Research [47].

2. Environmental Management (four articles) in the journals Sustainability [65], Journal of Cleaner Production [44], Agricultural and Food Economics [66], and Journal of Sustainable Forestry [67].

3. Tourism (four articles) in the journals, Journal of Tourism, Culture, and Territorial Development [68], Tourism [69], Tourism Management Perspectives [43], and International Journal of Tourism Research [53]. 
4. Information and Technology Management (four articles) in the journals, Interdisciplinary Studies Journal [70], Idimt-2015: Information Technology and Society Interaction and Interdependence [71], Kybernetes [72], and International Journal of Information Technology and Management [73].

5. Social Science (1 article) in the journal Social and Behavioral Sciences [54].

Figure 2 illustrates the number and the year of publications of the selected articles. As shown in Figure 2, 2009 is the first year in which there some (two) publications that fulfill our research criteria. It can be noted that, two third of the selected articles have been published in the most recent years, precisely 2015, 2016, and 2017.

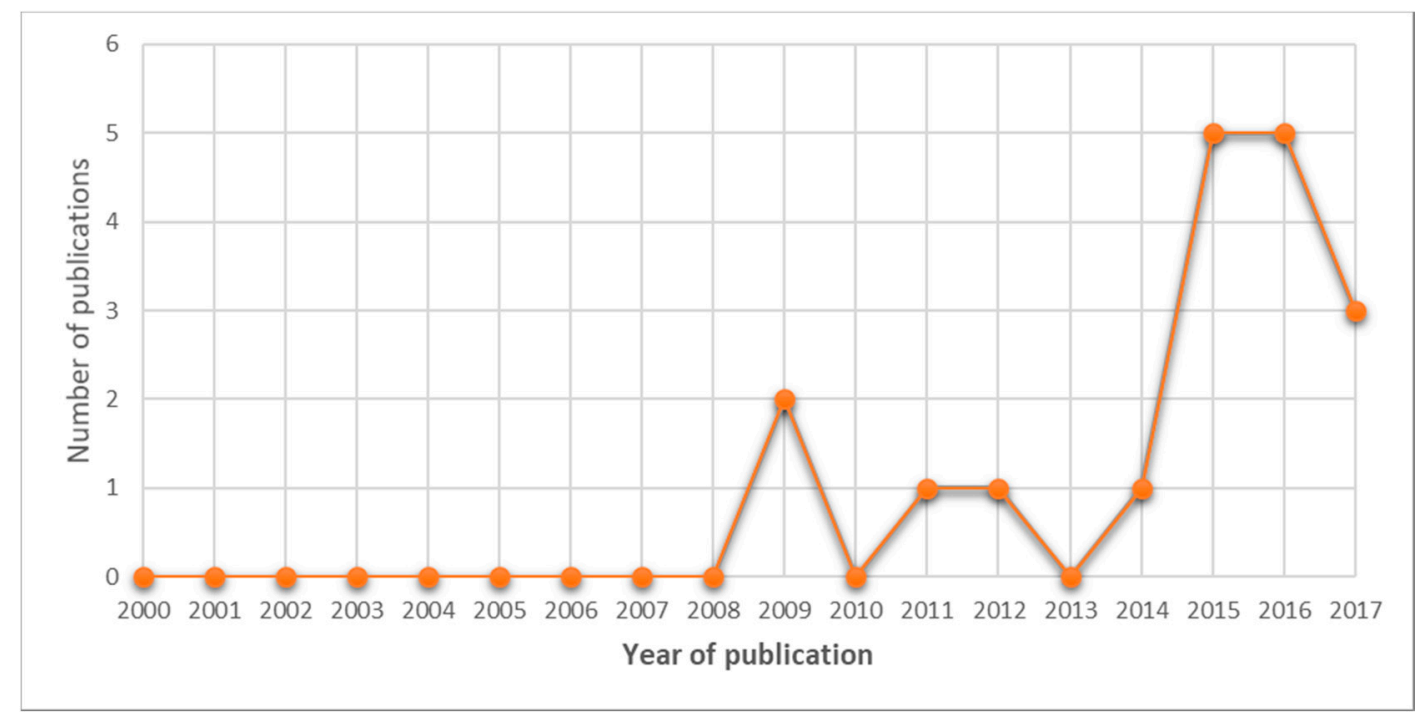

Figure 2. Number of published articles (2000-1 November 2017).

Table 1 presents chronologically an overview of the selected articles specifying five disciplines, the name of the authors together with the publication year, the research purpose, the adopted framework, the level of analysis, and the subcategory of tourism investigated. As shown in the column for the research purposes, 11 articles conduct business model analysis based on certain selected frameworks in order to explore success factors as well as influencing factors related to performance and the business model configurations. As a result, their level of analysis is concentrated more on the company level than on the industry level, and to an even lesser extent on the product level. With regard to the frameworks that are applied, 10 of the studies use business model-related frameworks either through qualitative or quantitative research. Among the frameworks, the Canvas framework is the one used most often (four articles out of 10).

Table 1 also shows that the articles concern four main types of nature tourism: agritourism and rural tourism, ecotourism, sport tourism, and various services within the nature context. From this first analysis, several aspects can be noted. None of the journals have published more than one article concerning business models. This can be interpreted as a possible lack of debate, or interest in initiating a debate, concerning business models in nature tourism. Moreover, considering the year of publication, two-thirds of the articles were published within the last three years of the selected time period 2000-2017. This confirms that scholars have only recently started to apply the business model concept within the context of nature tourism. 
Table 1. An overview of the reviewed articles.

\begin{tabular}{|c|c|c|c|c|c|}
\hline Discipline & Research Author(s) & Research Purpose & Framework & Level of Analysis & Type of Tourism \\
\hline \multirow{5}{*}{$\begin{array}{l}\text { Business, Management } \\
\text { and Marketing }\end{array}$} & Peric et al. [61] & $\begin{array}{l}\text { Incorporation of tourism } \\
\text { experience into BM concept }\end{array}$ & & Product and industry & Sport tourism \\
\hline & Di Gregorio [62] & Analysing place-based BMs & Place-based BM & Company and industry & Agritourism \\
\hline & Brannon and Wiklund [63] & $\begin{array}{l}\text { Investigating the } \\
\text { relationships between BMI } \\
\text { and performance }\end{array}$ & BMI & Company & $\begin{array}{l}\text { Winery tourism, } \\
\text { agritourism }\end{array}$ \\
\hline & Peric and Wise [64] & $\begin{array}{l}\text { Conceptualizing tourism } \\
\text { experience and value } \\
\text { offering }\end{array}$ & $\begin{array}{l}\text { BM framework by Johnson et al. }{ }^{1}[74] \\
\text { and experience-based framework by } \\
\text { Pine and Gilmore }{ }^{2}[75]\end{array}$ & Company & Sport tourism \\
\hline & Hojman and Hunter-Jones [47] & $\begin{array}{l}\text { Wine tourism played role in } \\
\text { strategy-making of winery } \\
\text { industry }\end{array}$ & & Company and industry & Wine tourism \\
\hline \multirow{4}{*}{$\begin{array}{l}\text { Environmental } \\
\text { Management }\end{array}$} & Broccardo et al. [65] & $\begin{array}{l}\text { BMIs' key success factors in } \\
\text { rural sustainable } \\
\text { development }\end{array}$ & $\begin{array}{l}\text { BM Canvas and Schaltegger et al.' } \\
\text { sustainability approach [28] }\end{array}$ & Company and industry & Agritourism \\
\hline & Scheepens et al. [44] & $\begin{array}{l}\text { Design of SBMs using three } \\
\text { dimensions: costs, eco-costs, } \\
\text { and market value. }\end{array}$ & $\begin{array}{l}\text { EVR }^{3} \text { Model, Circular Transition } \\
\text { Framework, and PSS }\end{array}$ & Product and industry & Water tourism \\
\hline & Torquati et al. [66] & $\begin{array}{l}\text { Examining multi-functional } \\
\text { farm BMs }\end{array}$ & BM Canvas and entrepreneurial models & Company & $\begin{array}{l}\text { Agritourism and rural } \\
\text { tourism }\end{array}$ \\
\hline & Bishop et al. [67] & $\begin{array}{l}\text { Exploring SBM for } \\
\text { biodiversity conservation } \\
\text { and key success factors }\end{array}$ & & Industry & Ecotourism \\
\hline
\end{tabular}


Table 1. Cont

\begin{tabular}{|c|c|c|c|c|c|}
\hline Discipline & Research Author(s) & Research Purpose & Framework & Level of Analysis & Type of Tourism \\
\hline \multirow{4}{*}{ Tourism } & Cannas [68] & $\begin{array}{l}\text { Analyzing sustainable } \\
\text { management of a cultural } \\
\text { heritage }\end{array}$ & Sustainable development and SBM & Company & $\begin{array}{l}\text { Cultural heritage } \\
\text { tourism, rural tourism }\end{array}$ \\
\hline & Fasone et al. [69] & $\begin{array}{l}\text { Exploring } \\
\text { customer-oriented BMs }\end{array}$ & Customer-centered BM & Company & $\begin{array}{l}\text { Accommodations in a } \\
\text { mountainous area }\end{array}$ \\
\hline & Sarkar and Sinha [43] & BM within ecotourism & & Industry & Ecotourism \\
\hline & Huang et al. [53] & $\begin{array}{l}\text { Introducing a new BM for } \\
\text { e-commerce }\end{array}$ & BM framework by Afuah and Tucci ${ }^{4}[76]$ & Company & $\begin{array}{l}\text { Traditional food } \\
\text { souvenir tourism }\end{array}$ \\
\hline \multirow{4}{*}{$\begin{array}{c}\text { Information and } \\
\text { Technology Management }\end{array}$} & Alamäki and Dirin [70] & $\begin{array}{l}\text { Describing the development } \\
\text { process of digital } \\
\text { service-oriented BMs }\end{array}$ & & Product and industry & $\begin{array}{l}\text { Mobileapps in } \\
\text { outdoor tourism (as } \\
\text { guide) }\end{array}$ \\
\hline & Pucihar et al. [71] & $\begin{array}{l}\text { Co-creation of innovative } \\
\text { tourism services }\end{array}$ & BM Canvas & Company and industry & $\begin{array}{l}\text { Tourism services in } \\
\text { nature context }\end{array}$ \\
\hline & Peric and Djurkin [72] & $\begin{array}{l}\text { Development of a new } \\
\text { approach in destination } \\
\text { management based on } \\
\text { social responsibility }\end{array}$ & & Company and industry & Local tourism \\
\hline & Hsiang et al. [73] & $\begin{array}{l}\text { Innovations in BMs } \\
\text { promoting national tourism } \\
\text { development }\end{array}$ & & Industry & $\begin{array}{l}\text { Tourism websites } \\
\text { from farms and } \\
\text { national parks }\end{array}$ \\
\hline Social Science & Rusu [54] & $\begin{array}{l}\text { Examining the innovation } \\
\text { impact on BM }\end{array}$ & BM Canvas & Company & $\begin{array}{l}\text { A small travel agency } \\
\text { in speleotherapy } 5 \\
\text { tourism }\end{array}$ \\
\hline
\end{tabular}


In this regard, some key points regarding the value structure and source of value creation can be identified. What is emphasized as the source of value creation by ecotourism, rural tourism, and agritourism stems from a rather similar logic. For example, the value creation source is related to location-specific capabilities such as "local embeddedness" by Di Gregorio [62], as "local heritage" by Cannas [68], and as "community-based" structures by Peric and Djurkin [72] and Sarkar and Sinha [43]. Geissdoerfer et al. [37] assert that sustainable value created through environmental, social, and economic effectiveness, efficiency, and resilience, and that stakeholder management refers to collaboration with multiple stakeholders and is essential to overcome a firm-centric approach to value creation [37].

Other aspects can be noted concerning innovation, destination management, co-creation, and specifically customer-related aspects. Across the literature, 15 articles analyze new products, processes, and more importantly, new business models to serve their research purpose (see Table 2 and related statements following this table). Among the studies chosen to emphasize the industry as well, only five articles explicitly provide insight regarding destination management. Here, proper and effective involvement of governmental organizations and policy-makers is regarded as crucial in tourism legislation $[43,67,72]$, as it can simultaneously facilitate firm performance and help the industry reduce costs [44], and can promote the businesses in this industry [73]. In the case of sustainable business models in nature tourism context $[43,44,67,72]$, it is argued that this concept is based on the combination of the concept of business model together with the concepts of "sustainable value creation", "stakeholder management", and "long term perspective" [37].

The co-creation concept and the role of stakeholders are among the mentioned concerns and purposes of four studies that discuss the active engagement of stakeholders within the value network [72,73] and users' experiments [70,71]. Finally, two other articles address other features of business model design, specified as customer interface through information processes [63], and customer segmentation [47].

\subsection{Further Analysis of the Literature}

The selected articles were reviewed with a focus on the research questions and the relevant aspects in terms of business model conceptualization and operationalization, as well as sustainability. The analysis and findings are illustrated in Table 2 and described in the following text.

The applied categories relative to conceptualization and operationalization that are shown in the table are based on the proposal by Massa et al. [77]. The category "descriptive tool" refers to the conceptualization of a business model through empirical demonstration of the firms' activities and their outcomes, known as value creation and capturing. Within the category "cognitive schema", the business model concept concerns cognitive interpretations and perceptions regarding an "image" of real activities and systems instead of real ones. When the business models are understood as "conceptual tools", the business model structure is usually described.

With regard to the operationalization of the business model concept, Reinhold et al. [8] claim that the way the business model concept is defined can determine how business models can be operationalized. Following the three categories of conceptualization, three approaches to operationalization are determined accordingly and shown in the table. Defining business models through descriptive tool leads to a "positivistic stance" in which activities are measured and observed directly. When business models are viewed as cognitive schemas, the perspective adopted is qualified as a "constructivist stance"; here, researchers tend to outline activities and relationships through managers' language. Finally, when the business model concept is understood as a conceptual tool, various frameworks (e.g., Canvas) are applied to its operationalization and such a perspective can be qualified as a "predefined stance". In accordance with the studies of Reinhold et al. [1] and Massa et al. [77], the two constructs of conceptualization and operationalization are regarded within the same category, as shown in Table 2. 
With regard to sustainability, based on the literature, the categories include environmental, social, and economic aspects and innovation [50-52]. Here, the focus is on the various types of innovation identified by Hjalager [52]: product/service, process, management, marketing, and institutional.

Table 2. Summarized findings related to the research questions.

\begin{tabular}{|c|c|c|c|c|c|c|c|}
\hline \multirow[b]{3}{*}{ Articles } & \multicolumn{7}{|c|}{ Business Models in Nature Tourism } \\
\hline & \multicolumn{3}{|c|}{ Conceptualization and Operationalization } & \multicolumn{4}{|c|}{$\begin{array}{l}\text { Sustainability } \\
\end{array}$} \\
\hline & $\begin{array}{l}\text { Descriptive } \\
\text { Tool/ } \\
\text { Positivistic } \\
\text { Stance }\end{array}$ & $\begin{array}{c}\text { Cognitive } \\
\text { Schema/ } \\
\text { Constructivist } \\
\text { Stance }\end{array}$ & $\begin{array}{l}\text { Conceptual } \\
\text { Tool/ } \\
\text { Predefined } \\
\text { Stance }\end{array}$ & Environmental & Social & Economic & Innovation \\
\hline Di Gregorio (2017) [62] & & & & & & & $\begin{array}{c}\text { Institutional } \\
\text { Process } \\
\end{array}$ \\
\hline \multicolumn{8}{|l|}{ Peric et al. (2017) [61] } \\
\hline Broccardo et al. (2017) [65] & & & & & & & Institutional \\
\hline Cannas (2016) [68] & & & & & & & Management \\
\hline \multicolumn{8}{|l|}{ Fasone et al. (2016) [69] } \\
\hline \multicolumn{8}{|l|}{$\begin{array}{c}\text { Brannon and } \\
\text { Wiklund (2016) [63] }\end{array}$} \\
\hline Scheepens et al. (2016) [44] & & & & & & & Institutional \\
\hline \multicolumn{8}{|l|}{ Rusu (2016) [51] } \\
\hline Torquati et al. (2015) [66] & & & & & & & Marketing \\
\hline \multicolumn{8}{|l|}{ Alamäki and Dirin (2015) [70] } \\
\hline Sarkar and Sinha (2015) [43] & & & & & & & Process \\
\hline \multicolumn{8}{|l|}{ Peric and Wise (2015) [64] } \\
\hline \multicolumn{8}{|l|}{ Pucihar et al. (2015) [71] } \\
\hline Peric and Djurkin (2014) [72] & & & & & & & Institutional \\
\hline \multicolumn{8}{|l|}{$\begin{array}{l}\text { Hojman and Hunter-Jones } \\
\text { (2012) [47] }\end{array}$} \\
\hline \multicolumn{8}{|l|}{ Hsiang et al. (2011) [73] } \\
\hline Bishop et al. (2009) [67] & & & & & & & Institutional \\
\hline Huang et al. (2009) [53] & & & & & & & \\
\hline
\end{tabular}

It can be noted that eight articles apply the business model concept as a conceptual tool that becomes operationalized within a business model-related framework; among them, Canvas is the most popular $[53,54,65,66,71]$, which can stem from its flexibility and analytical approach based on the description of the business through the identification of some main components [20]. Here, in addition to the business model-related frameworks, some scholars use other frameworks and models simultaneously. For example, models used include the sustainability framework by Schaltegger et al. [28,65], the Eco-Costs Value Ratio model [44], the sustainable development and sustainable business model framework [68], entrepreneurial models [66], and Pine and Gilmore's [75] experience-based framework [64].

Nine studies tend to explore and describe the business model concept empirically as a "descriptive tool". Established upon what is claimed by Massa et al. [77], this approach is accompanied by testing hypotheses regarding the related role of business models, as further evidenced by current research. For instance, through four propositions, Peric et al. [61] explore the relationship between sport experience and business models, whereas Brannon and Wiklund [63] analyze the relationships between performance and BMI. Likewise, Hojman and Hunter-Jones [47] use hypotheses to classify winery business models, while Fasone et al. [69] examine customers' perceived quality through three hypotheses. Moreover, as claimed by Massa et al. [77], the real attributes used when business models are viewed as descriptive tools can emerge through "novel ways of organizing business" and an "early notion of disruptive technologies/innovation" (p. 79). Examples can be testing the prototypes and technologies known as "minimum viable products" in Alamäki and Dirin [70] and the "collaborative commerce" mechanism in Hsiang et al. [73]. A business model as a descriptive tool describing social 
enterprise activities can also be defined across interactions between the company and the community, as in Peric and Djurkin [72].

Two articles can be clearly related to the positivistic stance approach by Massa et al. [77], explained as referring to the "sources of value creation inherent in innovative business models" (p. 79). This is the case for the usage of "location-specific resources to create and capture value", highlighted within "place-based business models" in Di Gregorio [62], and similarly, "deliver environmental benefits" through new business models in Bishop et al. [67].

One article is identified within the category of "cognitive schemas". This is the one by Sarkar and Sinha [43] who argue that no business model structure can be clearly recognized due to the novelty of the business. They understand business models as the mental perceptions of entrepreneurs rather than the empirical structures, and that is why "the lack of capacity in running the financial aspects of the business" (p. 104) occurs.

Among the eight articles that show sustainability-related concerns, seven refer to sustainable value proposition, which emphasizes the triple bottom line approach [43,44,65-68,72]. In addition, social and economic sustainability are highlighted across constructs like resilience [62], social benefits [66], social responsibility [72], social accessibility [68], and financial livelihood [43]. From this analysis, it can be noted that more emphasis is placed on social and economic sustainability and less on environmental sustainability. Seven studies deal explicitly with environmental concerns; these include through blending educational services with rural tourism services [66], creating value from ecosystem conservation [67], reducing the eco-burden of products [44], "environmental regeneration" [68], and raising awareness with a view to preserving rural landscapes [65,72]. Sarkar and Sinha [43] focus on ecotourism business models, noting a "trade-off between environmental sustainability and financial success" (p. 100).

With regard to the various types of innovation, eight articles emphasize innovation across various aspects. Institutional innovations are established through BMIs [44,62,65,72]; as well as through policy innovations [67]. Marketing innovations are configured across innovative channels in order to find potential customers [66], while management innovation can become embedded within novel usage of resources in value creation [62], and likewise within innovative management models [68] which can lead to other innovation types. On the other hand, policy innovation [67] can result in any type of innovation within businesses. Moreover, implementing new types of activities [43] can refer to process innovation. On the other hand, agritourism itself can be considered as a form of innovative tourism versus traditional agricultural business models $[62,65,66]$ as it "can be interpreted as a reconfiguration of the existing model of agricultural farms to a new one" [65] (p. 2).

Moreover, these eight articles differently address sustainability through business models; half of them benefit from applying the business models as conceptual tools through combining this concept with other sustainability-related frameworks $[44,65,66,68]$. Besides, the matter of dealing with sustainability-related issues can be reflected upon either changing the existing business models partially and focusing on some parts or generating a completely new one [78]. Regarding the former approach addressing sustainable business models, the study by Peric and Djurkin [72] focuses on the value network and interaction among them, while Scheepens et al. [44] introduce sustainable products argued to have "surplus value", whereas Bishop et al. [67] elaborate on creating value from preserving the ecosystem through cost and benefit analysis of using the environment as the resource. On the other hand, within the other five studies $[43,62,65-68]$ following the latter approach toward capturing sustainability, by developing a completely new business model, results in perceiving sustainable business models as a solution to preserve natural-cultural resources as well as provide the local community with enormous opportunities.

It can be added that within the articles with no sustainability-related concerns, the innovation concept is also highlighted. For example, institutional innovation is emphasized through innovative business models [50,61,73], BMIs [54,63], and collaborative innovation in providing services [71] which may result in the innovations in processes and services. Moreover, the service innovations are applied 
together with process innovation within the literature as unique experiences stemming from innovation designs [61] and innovative service apps through co-creative processes [70]. BMI is highlighted as encompassing various types of product, process, marketing, and organizational innovation [54].

\section{Conclusions}

This study has presented a literature review of the business models in nature tourism with particular focus on sustainability-related aspects. This review included 18 articles that have been analyzed in relation to the authors' understanding and use of the business model concept, and its relevance to environmental, economic, and social sustainability and innovation for sustainability.

The findings illustrate that the literature is still very sparse and the concept of business model in nature tourism is understood and used in a relatively limited way. This is in line with the broader tourism business model literature. Some of the investigated studies apply the business model concept based on the research narrative rather than a business model's real conceptualization, often without any clear definition of this concept.

Moreover, despite the cruciality of sustainability within nature tourism and its high relevance, only eight of the sampled articles include considerations and discussion of sustainability; seven of them concern the environmental aspect. This is clearly a research gap that could be filled by future studies. Thus, future endeavors can be dedicated to explore sustainable business models in nature tourism as its strong reliance on local communities, nature, and animals, and investigate how much business models need to evolve within various contexts in order to contribute to sustainability. Moreover, future studies can interpret the relationship between the extent which business models change and the development stage of existing business model.

The findings also suggest that the investigated nature tourism studies tend to adopt a static perspective on business models and as a consequence, innovation is not particularly investigated. Considering that sustainability is often viewed not as a "goal" but as a journey, this limitation can be regarded quite negatively. This finding can also be associated with the existence of few studies that build and configure every feature of their business model in relation to sustainability. Therefore, within future studies, researchers can explore the antecedents which lead to developing business models toward sustainability either partially or completely.

The definition of nature tourism that this study adopts is very broad and could be seen as conflicting with the understanding of sustainability as an adaptive approach. Future studies could investigate possible similarities and peculiarities among, for example, agritourism, rural tourism, and ecotourism. Another direction that could be pursued is the comparison of the sustainable business models in nature and non-nature tourism through empirical or conceptual studies, and an exploration of the extent to which sustainability is embedded within a business model design and how it is innovated. Last but not least, future attempts could be devoted to the comparison of tourism contingencies with other service-centered industries with regard to sustainable business models.

Author Contributions: Both authors made significant contributions.

Funding: The article processing charge was funded by the publication fund of UiT The Arctic University of Norway.

Conflicts of Interest: The authors declare no conflict of interest.

\section{References}

1. Martins, L.L.; Rindova, V.P.; Greenbaum, B.E. Unlocking the Hidden Value of Concepts: A Cognitive Approach to Business Model Innovation. Strateg. Entrep. J. 2015, 9, 99-117. [CrossRef]

2. Rauter, R.; Jonker, J.; Baumgartner, R.J. Going one's own way: Drivers in developing business models for sustainability. J. Clean. Prod. 2017, 140 Pt 1, 144-154. [CrossRef]

3. Wirtz, B. Business Model Management Design, Instruments, Success Factors; Gabler: Wiesbaden, Germany, 2011. 
4. Abdelkafi, N.; Täuscher, K. Business Models for Sustainability from a System Dynamics perspective. Org. Environ. 2016, 29, 74-96. [CrossRef]

5. World Commission on Environmental Development. Our Common Future; Oxford University Press: Oxford, UK, 1987.

6. Elkington, J. Cannibals with Forks-Triple Bottom Line of 21st Century Business; New Society Publishers: Stoney Creek, CT, USA, 1997.

7. Schaltegger, S.; Hansen, E.; Lüdeke-Freund, F. Business Models for Sustainability: Origins, Present Research, and Future Avenues. Organ. Environ. 2016, 29, 3-10. [CrossRef]

8. Reinhold, S.; Zach, F.J.; Krizaj, D. Business models in tourism: A review and research agenda. Tour. Rev. 2017, 72, 462-482. [CrossRef]

9. Coles, T.; Warren, N.; Borden, D.S.; Dinan, C. Business models among SMTEs: Identifying attitudes to environmental costs and their implications for sustainable tourism. J. Sustain. Tour. 2017, 25, 471-488. [CrossRef]

10. Valentine, P. Review: Nature-based tourism. In Special Interest Tourism; Weiler, B., Hall, C.M., Eds.; Belhaven Press: London, UK, 1992; pp. 105-127.

11. Hall, C.M.; Boyd, S. Nature-Based Tourism in Peripheral Areas. Development or Disaster? Channel View Publication: Clevedon, UK, 2005.

12. Kuenzi, C.; McNeely, J. Nature-Based Tourism. In Global Risk Governance: Concept and Practice Using the IRGC Framework; Renn, O., Walker, K., Eds.; Springer: Dordrecht, The Netherlands, 2008; pp. 155-178.

13. Dedeke, A. Creating sustainable tourism ventures in protected areas: An actor-network theory analysis. Tour. Manag. 2017, 61 (Suppl. C), 161-172. [CrossRef]

14. Newsome, D.; Moore, S.A.; Dowling, R. Natural Area Tourism: Ecology, Impacts and Management; Channel View Publications: Clevedon, UK, 2013.

15. Margaryan, L.; Fredman, P. Bridging outdoor recreation and nature-based tourism in a commercial context: Insights from the Swedish service providers. J. Outdoor Recreact. Tour. 2017, 17 (Suppl. C), 84-89. [CrossRef]

16. Bramwell, B. Sustainability. In Encyclopedia of Tourism; Jafari, J., Xiao, H., Eds.; Springer: Basel, Switzerland, 2016; pp. 914-915.

17. Zott, C.; Amit, R.; Massa, L. The Business Model: Recent Developments and Future Research. J. Manag. 2011, 37, 1019-1042. [CrossRef]

18. Teece, D.J. Business Models, Business Strategy and Innovation. Long Range Plan. 2010, 43, 172-194. [CrossRef]

19. Osterwalder, A.; Pigneur, Y. Business Model Generation: A Handbook for Visionaries, Game Changers, and Challengers; John Wiley \& Sons: Hoboken, NJ, USA, 2010.

20. Díaz-Díaz, R.; Muñoz, L.; Pérez-González, D. Business model analysis of public services operating in the smart city ecosystem: The case of SmartSantander. Fut. Gener. Comput. Syst. 2017, 76 (Suppl. C), 198-214. [CrossRef]

21. Boons, F.; Lüdeke-Freund, F. Business models for sustainable innovation: State-of-the-art and steps towards a research agenda. J. Clean. Prod. 2013, 45, 9-19. [CrossRef]

22. Afuah, A. Business Model Innovation: Concepts, Analysis and Cases; Routledge: New York, NY, USA, 2014.

23. Wirtz, B.W.; Pistoia, A.; Ullrich, S.; Gottel, V. Business Models: Origin, Development and Future Research Perspectives. Long Range Plan. 2016, 49, 36-54. [CrossRef]

24. Richardson, J. The business model: An integrative framework for strategy execution. Strateg. Chang. 2008, 17, 133-144. [CrossRef]

25. Beattie, V.; Smith, S. Value Creation and Business Models: Refocusing the Intellectual Capital Debate. Br. Account. Rev. 2013, 45, 243-254. [CrossRef]

26. Amit, R.; Zott, C. Creating value through business model innovation. MIT Sloan Manag. Rev. 2012, 53, 41-49.

27. Massa, L.; Tucci, C.L. Business Model Innovation. In Oxford Handbook of Innovation Management; Dodgson, M., Gann, D.M., Phillips, N., Eds.; Oxford University Press: Oxford, UK, 2014; pp. 420-441.

28. Schaltegger, S.; Lüdeke-Freund, F.; Hansen, E.G. Business cases for sustainability: The role of business model innovation for corporate sustainability. Int. J. Innov. Sustain. Dev. 2012, 6, 95-119. [CrossRef]

29. Bocken, N.; Short, S.; Rana, P.; Evans, S. A literature and practice review to develop sustainable business model archetypes. J. Clean. Prod. 2014, 65, 42-56. [CrossRef]

30. Lele, S.M. Sustainable Development: A Critical Review. World Dev. 1991, 19, 607-621. [CrossRef] 
31. Glavic, P.; Lukman, R. Review of sustainability terms and their definitions. J. Clean. Prod. 2007, 15, 1875-1885. [CrossRef]

32. Joyce, A.; Paquin, R.L. The triple layered business model canvas: A tool to design more sustainable business models. J. Clean. Prod. 2016, 135, 1474-1486. [CrossRef]

33. Faber, N.; Jorna, R.; van Engelen, M.L. The sustainability of "sustainability"-A study into the conceptual foundations of the notion of "sustainability". J. Environ. Assess. Policy Manag. 2005, 7, 1-33. [CrossRef]

34. Cavalcante, S.; Kesting, P.; Ulhøi, J. Business model dynamics and innovation: (Re)establishing the missing linkages. Manag. Decis. 2011, 19, 1327-1342. [CrossRef]

35. Boons, F.; Montalvo, C.; Quist, J.; Wagner, M. Sustainable innovation, business models and economic performance: An overview. J. Clean. Prod. 2013, 45 (Suppl. C), 1-8. [CrossRef]

36. Roome, N.; Louche, C. Journeying Toward Business Models for Sustainability: A Conceptual Model Found Inside the Black Box of Organizational Transformation. Org. Environ. 2015, 29, 11-35. [CrossRef]

37. Geissdoerfer, M.; Bocken, N.; Hultink, E. Design thinking to enhance the sustainable business modelling process-A workshop based on a value mapping process. J. Clean. Prod. 2016, 135, 1218-1232. [CrossRef]

38. Weaver, D.B. Sustainable Tourism: Theory and Practice; Elsevier Butterworth-Heinemann: Oxford, UK, 2006.

39. Pforr, C.; Reiser, D. Sustainable Tourism. In The SAGE International Encyclopedia of Travel and Tourism; Lowry, L.L., Ed.; SAGE Publications Ltd.: Thousand Oaks, CA, USA, 2017; pp. 1192-1193.

40. Bohdanowicz, P.; Zientara, P. Hotel companies' contribution to improving the quality of life of local communities and the well-being of their employees. Tour. Hosp. Res. 2009, 9, 147-158. [CrossRef]

41. Mihalič, T.; Žabkar, V.; Cvelbar, L.K. A hotel sustainability business model: Evidence from Slovenia. J. Sustain. Tour. 2012, 20, 701-719. [CrossRef]

42. Høgevold, N.M.; Svensson, G.; Padin, C. A sustainable business model in services: An assessment and validation. Int. J. Qual. Serv. Sci. 2015, 7, 17-33. [CrossRef]

43. Sarkar, R.; Sinha, A. The village as a social entrepreneur: Balancing conservation and livelihoods. Tour. Manag. Perspect. 2015, 16, 100-106. [CrossRef]

44. Scheepens, A.E.; Vogtländer, J.G.; Brezet, J.C. Two life cycle assessment (LCA) based methods to analyse and design complex (regional) circular economy systems. Case: Making water tourism more sustainable. J. Clean. Prod. 2016, 114 (Suppl. C), 257-268. [CrossRef]

45. Alegre, I.; Berbegal-Mirabent, J. Social innovation success factors: Hospitality and tourism social enterprises. Intern. J. Contemp. Hosp. Manag. 2016, 28, 1155-1176. [CrossRef]

46. Kathan, W.; Matzler, K.; Veider, V. The sharing economy: Your business model's friend or foe. Bus. Horiz. 2016, 59, 663-672. [CrossRef]

47. Hojman, D.E.; Hunter-Jones, P. Wine tourism: Chilean wine regions and routes. J. Bus. Res. 2012, 65, $13-21$. [CrossRef]

48. Schiller, B. Mind the gap: The current debate between states \& municipalities and online travel companies over the taxability of the remittance gap. J. State Tax. 2011, 29, 61-80.

49. Souto, J.E. Business model innovation and business concept innovation as the context of incremental innovation and radical innovation. Tour. Manag. 2015, 51, 142-155. [CrossRef]

50. Moscardo, G. Sustainable Tourism Innovation: Challenging Basic Assumptions. Tour. Hosp. Res. 2008, 8, 4-13. [CrossRef]

51. Gössling, S.; Hall, C.M.; Weaver, D. Sustainable Tourism Futures: Perspectives on Systems, Restructuring and Innovations; Routledge: London, UK, 2009.

52. Hjalager, A. A review of innovation research in tourism. Tour. Manag. 2010, 31, 1-12. [CrossRef]

53. Huang, T.-C.; Lee, T.J.; Lee, K.-H. Innovative e-commerce model for food tourism products. Int. J. Tour. Res. 2009, 11, 595-600. [CrossRef]

54. Rusu, B. The Impact of Innovations on the Business Model: Exploratory Analysis of a Small Travel Agency. Procedia Soc. Behav. Sci. 2016, 221 (Suppl. C), 166-175. [CrossRef]

55. Priskin, J. Assessment of natural resources for nature-based tourism: The case of the Central Coast Region of Western Australia. Tour. Manag. 2001, 22, 637-648. [CrossRef]

56. Torraco, R.J. Writing Integrative Literature Reviews: Using the Past and Present to Explore the Future. Hum. Resour. Dev. Rev. 2016, 15, 404-428. [CrossRef]

57. Webster, J.; Watson, R.T. Analyzing the Past to Prepare for the Future: Writing a Literature Review. MIS Q. 2002, 26, xiii-xxiii. 
58. Tranfield, D.; Denyer, D.; Smart, P. Towards a methodology for developing evidence-informed management knowledge by means of systematic review. Br. J. Manag. 2003, 14, 207-222. [CrossRef]

59. Seuring, S.; Müller, M. From a literature review to a conceptual framework for sustainable supply chain management. J. Clean. Prod. 2008, 16, 1699-1710. [CrossRef]

60. Mayring, P. Qualitative Content Analysis. Forum Qual. Soc. Res. 2000, 1. Available online: http://nbnresolving.de/urn:nbn:de:0114-fqs0002204 (accessed on 10 September 2018).

61. Peric, M.; Wise, N.; Dragičević, D. Suggesting a service research agenda in sports tourism: Working experience(s) into business models. Sport Bus. Manag. Int. J. 2017, 7, 58-76. [CrossRef]

62. Di Gregorio, D. Place-based business models for resilient local economies: Cases from Italian slow food, agritourism and the albergo diffuso. J. Enterp. Commun. People Glob. Econ. 2017, 11, 113-128. [CrossRef]

63. Brannon, D.L.; Wiklund, J. An analysis of business models: Firm characteristics, innovation and performance. Acad. Enterp. J. 2016, 22, 1-20.

64. Peric, M.; Wise, N. Understanding the delivery of experience: Conceptualizing business models and sports tourism, assessing two case studies in Istria, Croatia. Local Econ. 2015, 30, 1000-1016. [CrossRef]

65. Broccardo, L.; Culasso, F.; Truant, E. Unlocking Value Creation Using an Agritourism Business Model. Sustainability 2017, 9, 1618. [CrossRef]

66. Torquati, B.; Tancini, C.; Paffarini, C.; Illuminati, R. Empirical survey on business models of kindergarten farms. Agric. Food Econ. 2015, 3, 1-13. [CrossRef]

67. Bishop, J.; Kapila, S.; Hicks, F.; Mitchell, P.; Vorhies, F. New Business Models for Biodiversity Conservation. J. Sustain. For. 2009, 28, 285-303. [CrossRef]

68. Cannas, R. The Sustainable Tourism Management of Cultural Heritage: The Case of the Rosas Mine in Sardinia. Almatour. J. Tour. Cult. Territ. Dev. 2016, 7, 38-59. [CrossRef]

69. Fasone, V.; Hofer, S.; Scuderi, R. Hotels in a customer-centred business model: Empirical findings from Val Gardena. Tourism 2016, 64, 97-108.

70. Alamäki, A.; Dirin, A. Digital Service Design for Service-Oriented Business Models. Int. St. J. 2015, 4, 8-16.

71. Pucihar, A.; Lenart, G.; Borstnar, M.K.; Marolt, M. Business model design for a platform for the collaborative innovation of tourism services. In Proceedings of the IDIMT-2015, Information Technology and Society Interaction and Interdependence, Poděbrady, Czech Republic, 9-11 September 2015.

72. Peric, M.; Djurkin, J. Systems thinking and alternative business model for responsible tourist destination. Kybernetes 2014, 43, 480-496. [CrossRef]

73. Hsiang, C.; Chen, R.; Chen, Y.; Chen, C. A framework of Collaborative Commerce and internet organization business model innovation in the tourism industry: The case study of the Veterans Affairs Commission in Taiwan. Int. J. Inf. Technol. Manag. 2011, 10, 167-191. [CrossRef]

74. Johnson, M.; Christensen, C.; Kagermann, H. Reinventing your business model. Harv. Bus. Rev. 2008, 86, $50-59$.

75. Pine, B.; Gilmore, J. Welcome to the experience economy. Harv. Bus. Rev. 1998, 76, 97-105. [PubMed]

76. Afuah, A.; Tucci, C. Internet Business Models and Strategies: Text and Cases; McGraw-Hill: New York, NY, USA, 2003.

77. Massa, L.; Tucci, C.; Afuah, A. A critical assessment of business model research. Acad. Manag. Ann. 2017, 11, 73-104. [CrossRef]

78. Dentchev, N.; Rauter, R.; Jóhannsdóttir, L.; Snihur, Y.; Rosano, M.; Baumgartner, R.; Nyberg, T.; Tang, X.; Hoof, B.; Jonker, J. Embracing the variety of sustainable business models: A prolific field of research and a future research agenda. J. Clean. Prod. 2018, 194, 695-703. [CrossRef]

(C) 2018 by the authors. Licensee MDPI, Basel, Switzerland. This article is an open access article distributed under the terms and conditions of the Creative Commons Attribution (CC BY) license (http://creativecommons.org/licenses/by/4.0/). 